DOI https://doi.org/10.18551/rjoas.2020-12.04

\title{
SELECTION ANALYSIS OF BUMDES BUSINESS TYPES IN KADUNDUNG VILLAGE, LABUAN AMAS UTARA DISTRICT, HULU TENGAI DISTRICT, CENTRAL RIVER, KALIMANTAN SELATAN
}

\author{
Subagio Hani ${ }^{\star}$, Satoto Shinta Heru \\ Faculty of Economics and Business, Universitas Pembangunan Nasional Veteran \\ Yogyakarta, Indonesia \\ *E-mail: hanisubagio@upnyk.ac.id
}

\begin{abstract}
This study aims to assist the Kadundung village government in planning business activities through various planned and structured stages so that the choice of types of business that can support village economic growth can be determined according to the advantages possessed by Kadundung Village. This research was conducted using the Participatory Rural Appraisal method (PRA), namely by conducting studies on rural conditions which include mapping of village potentials, SWOT analysis and followed by Hierarchy Value Alignment (HVA) analysis to determine the type of selected business. The results showed that there were three types of businesses that could be carried out by BUMDes Desa Kadundung, namely making fruit chips, establishing cafeterias, and optimizing tent rental.
\end{abstract}

\section{KEY WORDS}

Village-owned enterprises, village potential mapping, selection of business types.

Based on website data www.bumdes.id it is known that out of a total of 74,546 new villages, only 18,446 villages have BUMDes. The question is why only a few have BUMDes? One of the causes of this condition is the fear of the Village Government if the BUMDes they have founded will have the same fate as the KUD or other economic enterprises. Government initiatives are only a name board. In an effort to avoid this, the village needs to be careful in mapping the potential and choosing the type of business that can guarantee sustainability and future development so that it can become an independent, strong BUMDes and become a source of active and passive income for the village.

Basically, many villages have not been able to conduct potential mapping and choose the type of business. Analysis in mapping this potential will help provide an overview of the choices of types of business that can later be analyzed and measured. In mapping this potential, it is necessary to have participatory planning that can be done using the technique Participatory Rural Appraisal (PRA) in which there is variables that are mapped specifically. Meanwhile, in selecting the type of business, you can use the analysis of strengths, weaknesses, opportunities, and threats or also known as SWOT analysis combined with Hierarchy Value Alignment (HVA) analysis or analysis used to find out the highest hierarchical value based on the value of the researched objects.

Kadundung Village is one of the villages located in the North Labuan Amas District, Hulu Sungai Tengah Regency. North Labuan Amas District has an area of 17,005.10 ha of which $63.51 \%$ consists of lebak, and $16.5 \%$ consists of rainfed rice fields. Irrigated rice fields are not available in this sub-district. This district is the third largest contributor to rice production in Hulu Sungai Tengah Regency with an average production of 50 tons per hectare. This is because most of the area is in the form of lebak which has a high fertility rate (BPS Kabupaten Hulu Sungai Tengah, 2015).

So far, land use has not been maximized due to limited resources. Village-owned enterprises (BUMDes) can be a means to support the realization of village independence and improve the welfare of the Kadundung village community. However, in carrying out BUMDes activities, a business activity plan is needed so that it can support the improvement of the village economy and optimize its resources. 
BUMDes Desa Kadundung was established in 2016 based on Village Regulation Kadundung Number 02 of 2016 dated April 11, 2016 under the name "Rakat Mufakat". The Kadundung Village business fields as stated in the Village Regulation for the Establishment of BUMDes include services and trade, agriculture, livestock, public works, financial services, fisheries, transportation, forestry, and plantations. However, over time, this BUMDes has not been able to run optimally and has not been able to support the independence of the village economy. Limited resource capacity and lack of socialization of the roles and functions of BUMDes have made BUMDes Desa Kadundung stagnant in their activities. Thus, to maintain the continuity of the BUMDes, it is necessary to carry out a comprehensive study including mapping the village potential and selecting the type of business so that it can support the running of BUMDes in the future.

This study aims to assist the Kadundung village administration in planning business activities through various planned and structured stages so that the choice of business types that can support village economic growth can be determined in accordance with the advantages possessed by Kadundung Village. This is very necessary considering that mapping and selecting the type of business will determine the success and sustainability of the BUMDes which is expected to be able to support the independence of the village economy and empowerment of village communities.

\section{LITERATURE REVIEW}

The Concept of Village-Owned Enterprises. According to Law No. 6 of 2014, VillageOwned Enterprises (BUMDes) are business entities whose entire or most of the capital is owned by the village through direct participation originating from separated village assets to manage assets, services, and other businesses for the greatest possible welfare of the community. village. Village-owned enterprises (BUMDes) can also be defined as village business institutions that are managed by the community and village government in an effort to strengthen the village economy and are formed based on the needs and potential of the village (Pusat Kajian Dinamika Pembangunan System, 2007).

The potential of the village in this case becomes the benchmark for establishing a village business. According to the Minister of Home Affairs Regulation Number 39 of 2010, Village Business is a type of business in the form of village economic services such as service businesses, distribution of nine basic commodities, trade in agricultural products, as well as industry and folk crafts (Bambang, 2015).

BUMDes is a pillar of economic activity in the village that serves as a social institution(social institution) and commercial(commercial institution).BUMDes as a social institution sides with the interests of the community through its contribution in providing social services. Meanwhile, as a commercial institution, it aims to seek profits through the supply of local resources (goods and services) to the market (Syahrul, 2019).

Based on the Regulation of the Ministry of Villages, Development of Disadvantaged Areas and Transmigration Number 4 years concerning Establishment, Administration and Management, and Disbanding of Village-Owned Enterprises, the objective of BUMDes is to improve the village economy, optimize village assets for community welfare, increase community empowerment in managing potential village economy, develop business plans for partnerships between villages and / or with third parties, create market advantages and networks that support community service needs, create jobs, improve community welfare through improved public services and village economic growth, and increase villagers' income and original income village.

The Principles of BUMDes Management. According to Ridwan (2104) there are 6 principles in managing BUMDes, namely:

a. Cooperative, all components involved in BUMDes must be able to work together in developing and maintaining their business;

b. Participatory, all components involved in BUMDes are willing to volunteer or are willing to provide support and donations that can support the achievement of BUMDes businesses; 
c. Emancipative, all components involved in BUMDes have the same position regardless of class, ethnicity, and religion;

d. Transparent, all activities that can affect the public interest must have easy and transparent access for all people;

e. Accountable, all business activities must be accounted for both technically and administratively;

f. Sustainable, all business activities must be able to be developed and preserved by the community in the BUMDes container.

Classification of BUMDes Business Types. In selecting the type of business, several sectors that can become BUMDes business alternatives include:

a. Cultivating, namely BUMDes carries out a good cultivation process in the agricultural, livestock, fishery, and forestry sectors. The benefits that are felt by the community directly are the absorption of more workers in this sector. Examples of types ofbusiness cultivating include organic rice cultivation, black soybean cultivation, and so on;

b. Processing, namely BUMDes runs a business of processing natural products, both from natural products from the agricultural, livestock, fishery and forestry sectors as a result of the raw products produced in the village. Examples of types ofbusiness processing are fruit chips processing, VCO oil processing, fish crackers, fish fillets, meublekayu, and so on;

c. Serving, namely BUMDes running a "social business" that serves residents, namely to provide public services to the community. In other words, BUMDES provides social benefits to community members. Examples of types of business Serving are village drinking water business, both clean water management and drinking water management (distilled), village electricity business, food barns, and so on;

d. Banking, namely BUMDes, runs a "money business", which meets the financial needs of rural communities with interest that is lower than the interest money that villagers get from village loan sharks or conventional banks. Examples of types of banking businesses are: Village banks or village credit institutions or village microfinance institutions, revolving fund business units, etc;

e. Renting, namely BUMDes, runs a rental service business to serve the needs of the local community and at the same time to earn village income. Examples of types of business Renting's are: tractor rental, party tools, meeting buildings, shop houses, land, and so on;

f. Brokering, namely BUMDes, becomes an "intermediary institution" that connects agricultural, fishery, livestock and forestry commodities to the market or so that farmers have no trouble selling their products to the market, or Brokering in the sense that BUMDes sells services to residents and community businesses. Examples of types of businesses brokering are: Farmer partnership services with processing companies, electricity payment services, PAM, Telp, Motor Vehicle Tax Extension Services, etc. Villages can also establish village markets to market products produced by the community;

g. Trading namely BUMDes running a business that produces and / or trades certain goods to meet the needs of the community and is marketed on a wider market scale. Examples of types of business trading include: Ice factories, agricultural products, agricultural production facilities, etc;

h. Holding, namely BUMDes as a "joint venture", or as the parent of business units in the village, where each unit is independent, is regulated and synergized by BUMDES in order to grow a joint business.

Planning a BUMDes Business Unit. In planning a BUMDes business unit, it is necessary to conduct a study on the identification of village potential and community needs that must be met. According to Wijaya (2018: 170) in Syahrul (2019, the purpose of the feasibility study for determining the BUMDes business unit includes other activities: a) Taking into account the internal conditions of the village (village potential and community needs) and village external (opportunities and threats for business development) as a reference for managers unit. b) solidifying economic ideas, c) planning human resources (HR), especially in order to be able to prepare qualified people as business unit managers, d) designing business unit organizations, e) calculating business opportunities and risks, and f) 
determining the type of business which is possible and profitable. Identification of potential areas and demographics, including:

a. Regional potential is related to the usefulness of resources for the region concerned and in relation to relations between regions. Regional potential is a resource that can be utilized for an area, both human resources and natural resources; village;

b. Natural resources are natural resources which are available in large quantities in the

c. Human resources, namely the human potential itself that can process natural resources to meet their needs;

d. Demography, which is the study of the dynamics of the human population. It includes the size, structure and distribution of population, and how population changes over time due to birth, death, migration and aging;

e. Age range or population division based on age in a certain range, for example the population in the age range $0-10$ years and $11-20$ years;

f. Social class. Social class makes consumers buy certain products because these products are favored by members of their own social class and higher classes, and consumers may avoid other products because they feel they are products of a "higher class". low";

g. Lifestyle, is a lifestyle that determines how a person chooses to use time, money and energy and embody values, tastes and preferences. Economic demographics here are very useful to analyze to find out how people use their money and where people spend more of their money.

Studies on the SWOT. SWOT analysis is a strategic planning technique useful for evaluating Strength and weakness, opportunities and threats in a project, both projects are ongoing or in the planning of new projects. SWOT analysis consists of 4 basic components, namely:

a. Strength, which is something that provides the advantages / advantages compared to others, for example in the choice of the type of business, its power is abundant availability of raw materials, human resources that allow the execution, tools and machines are available, and so on.

b. Weakness, which is a characteristic related to weakness. For example in choosing the type of business, the weakness is that raw materials are not available, there are not many human resources and do not understand, tools and machines are still manual, and so on.

c. Opportunities, the opportunities that can be utilized for BUMDes to be able to develop later in life. For example, because the market is still large, when a business is selected, the chances of success are high.

d. Threats, namely the threat to be faced by BUMDes that can hinder development, such as the presence of thuggery, and so on.

\section{METHODS OF RESEARCH}

This research uses the method action research, namely activities and / or corrective actions for something that is planned, implemented, and evaluated systematically so that its validity and reliability reach the research level (Gunawan, 2004). Action research is carried out jointly at least two people, namely between researchers and participants or clients who come from academia or society. The research was conducted at BUMDes "Rakat Mufakat" Kadundung Village during March to August 2020. The method of analysis in this study used the SWOT analysis method. SWOT analysis is a systematic way of identifying the factors and strategies that illustrate the best fit between these strategies. This analysis is based on the assumption that an effective one will maximize strengths and opportunities and minimize weaknesses and threats. Strength and weakness in the SWOT analysis, also known as internal factors (Internal Factor), whereas Opportunities (Opportunities) and threats (Threats) is also called the external factor(External Factor). The strategies for these two conditions are also the Internal Strategy Factor (IFAS) and the External Strategy Factor (EFAS). 


\section{RESULTS OF STUDY}

Kadundung Village has an area according to its use amounting to $675 \mathrm{Ha}$. more land use is in rice fields, which is 200 hectares, and horticultural plantations as much as 100 hectares. In terms of climatic conditions, Kadundung Village has a rainfall of $218.5 \mathrm{~mm}$ with a number of rainy months of $5-6$ months with a daily average temperature of $25-35^{\circ} \mathrm{C}$ and the height above sea level is 3 meters above sea level. Kadundung Village has a distance of $2 \mathrm{~km}$ to the sub-district capital with a distance of 10 minutes for a motorized drive and 35 minutes by foot, while the distance to the district / city capital is $18 \mathrm{~km}$ with a travel time of 30 minutes by motorized drive and 180 minutes. on foot, and for the distance to the provincial capital as far as $125 \mathrm{~km}$ with a travel time of 5 hours by motorized drive and 50 hours for walking.

Kadundung Village has great potential in the agricultural sector because based on village data, there are 330 families of agricultural land owners where the majority of the land is used for 200 hectares of paddy rice, 5 hectares of chillies, and 5 hectares of tomatoes and the marketing carried out so far is some are sold to the market, some to middlemen and retailers, some are sold directly to consumers and some are not sold, namely when there is an imbalance in market prices. For other sectors such as the forestry sector, Kadundung Village lacks potential so that there are no forestry plants in Kadundung Village. For the plantation sector, Kadundung Village has plantation potential such as coconut plantations covering an area of 2.5 hectares with a potential yield of 7 tons / ha, while rubber plantations covering an area of 1 hectare with a potential yield of 6 tons / ha. As for the livestock sector, the livestock that are mostly cultivated in Kadundung Village are cows, native chickens, ducks, geese, quails, rabbits, and goats, with livestock production in the form of eggs and meat. For the fisheries sector, Kadundung Village has a freshwater fish cultivation production facility, namely a pond or pond. Utilization of these production facilities is for the cultivation of tilapia, catfish, cork, sepat, and carp.

Kadundung Village has a population of 1,802 people consisting of 857 men and 945 women. The number of families in Kadundung Village is 657 families with a population density of 176 people / km. Based on the education level of the population, it is known that the majority of the population in Kadundung Village has graduated from SMP / equivalent, namely 269 people and 274 people who graduated from high school / equivalent. The majority of the people in Kadundung Village are farmers, namely 269 people. Based on data from Kadundung Village in 2015 , it is known that the average income per family member is Rp. 500,000, - up to Rp. 5,000,000, -.

According to Law Number 32 of 2004 and Government Regulation No. 72 of 2005 concerning Villages that the establishment of BUMDes must be adjusted to the needs and potential of existing villages. On this basis, before establishing a BUMDes business, it is necessary to map the village potential. Mapping the potential of this village will later be used as a basis for determining the types of businesses that will and can be implemented. This mapping is very important so that the form of business that is established is in accordance with the potential, needs and conditions of the village concerned and can have a positive impact on the community and the BUMDes itself.

Based on the mapping of village potential through village maps, identification of habits and seasons and village partnership diagrams that have been carried out in a participatory manner, the following data were obtained:

Based on the results of the village potential mapping in Table 1, it appears that Kadundung Village has the potential for natural products that have not been fully utilized. Kadundung Village has the potential to produce fruit. Various kinds of fruit can be produced because the land conditions are very supportive, but they can only be sold at low prices when the stock is abundant. From the market point of view, as the third largest rice producer in Hulu Sungai Tengah Regency, farmers have yet to get results that can improve their welfare because the majority of farmers still sell their crops to middlemen at low prices.

From an economic point of view, the large population and the tendency to like processed products outside the region indicate the high interest of the Kadundung villagers 
for various processed products from the produce of the land. The number of agricultural tools and machines that have not been fully utilized can be used by BUMDes to encourage the use of these facilities to support the production of products that have a selling value more than the natural products produced.

Table 1 - Results of Kadundung Village Potential Mapping

\begin{tabular}{|c|c|c|}
\hline No. & Identification & Potential \\
\hline 1. & Nature & $\begin{array}{l}\text { 1. Large agricultural land } \\
\text { 2. There is freshwater fish cultivation production } \\
\text { 3. Sufficient land for coconut and rubber plantations } \\
\text { 4. There is livestock cultivation } \\
\text { 5. Fruit producer } \\
\text { 6. Unutilized village land }\end{array}$ \\
\hline 2. & Market & $\begin{array}{l}\text { 1. The demand for rice production is very high } \\
\text { 2. Hastent rentals } \\
\text { 3. The crop is sold to middlemen at a low price }\end{array}$ \\
\hline 3. & Social & $\begin{array}{l}\text { 1. Certain areas in the Kadundung Village area have habits that tend to be conservative and do not } \\
\text { want to accept changes } \\
\text { 2. Community leaders are actively involved in village activities } \\
\text { 3. BUMDes have not built many partnerships with associations or outside communities }\end{array}$ \\
\hline 4. & Economy & $\begin{array}{l}\text { 1. Total population } 1,802 \text { people } \\
\text { 2. High purchasing power } \\
\text { 3. Prefers processed products outside the region } \\
\text { 4. Like products with attractive appearance }\end{array}$ \\
\hline 5. & Technology & Many agricultural equipment and machinery resources have not been fully utilized \\
\hline 6. & Human resources & Community participation in village activities is quite high \\
\hline
\end{tabular}

The results of the mapping of village potential from the social side show that BUMDes need to establish more communication with various supporting parties such as agencies, banks and others. This will greatly help BUMDes to develop and improve the community's economy. From the results of the village potential mapping study, a SWOT analysis was carried out to find strategic advantages that could be exploited in strategies that were useful for the development of BUMDes in Kadundung Village. The results of the SWOT analysis for Kadundung Village are presented in Table 2.

After knowing the strengths, weaknesses, opportunities and threats of Kadundung Village, further analysis was carried out to determine the policy strategy for the development of the Village-owned BUMDes in Kadundung Village. The analysis was performed using the calculation of IFAS (internal factor analysis strategy) factor and EFAS (external analysis strategy). The results of the calculation of weights and scores of IFAS and EFAS are presented in Table 3.

Table 2 - Results of the SWOT Analysis for Kadundung Village

\begin{tabular}{|c|c|c|}
\hline No & Component & Analysis \\
\hline 1. & Strengths & $\begin{array}{l}\text { 1. Large agricultural land } \\
\text { 2. High rice production } \\
\text { 3. Owning freshwater fish farming production facilities } \\
\text { 4. Adequate land for coconut and rubber plantations } \\
\text { 5. There is livestock cultivation which has livestock production in the form of meat and eggs } \\
\text { 6. Abundant fruit yield } \\
\text { 7. Has tents that can be rented } \\
\text { 8. Have resources for agricultural equipment and machinery that can be utilized }\end{array}$ \\
\hline 2. & Weaknesses & $\begin{array}{l}\text { 1. Do not have the resources that can manage the maximum rental of tents } \\
\text { 2. Not able to build partnerships with communities other than sub-districts } \\
\text { 3. Do not have the ability to manage village land which is still unemployed }\end{array}$ \\
\hline 3. & Opportunity & $\begin{array}{l}\text { 1.BUMDes can act as a distributor of agricultural, livestock, fishery and plantation products } \\
\text { 2. BUMDes can manage rental tents } \\
\text { 3. Develop processed fruit products } \\
\text { 4. Open village shops to help sell cultivation products } \\
\text { 5. Manage untapped village lands such as open a culinary stall }\end{array}$ \\
\hline 4. & Threats & $\begin{array}{l}\text { 1. Competition with processed products from outside the region that are already favored by the village } \\
\text { community } \\
\text { 2. Sufficient capital is needed in utilizing idle village land } \\
\text { 3. Marketing of superior village products is not optimal } \\
\text { 4. The market share of tent rental services is still untapped } \\
\text { 5. Business competition with middlemen } \\
\text { 6. Agricultural products are highly seasonal }\end{array}$ \\
\hline
\end{tabular}


Table 3 - BUMDes Development Policy Strategy

\begin{tabular}{|c|c|c|c|c|}
\hline No & Internal Strategic Factors (IFAS) & Score & Weighted & Score \\
\hline & Strength & & & \\
\hline 1 & Wide agricultural land & 0.097 & 8 & 0.776 \\
\hline 2 & High yields of rice production & 0.103 & 8 & 0.824 \\
\hline 3 & Have adequate production facilities for freshwater fish, farming coconut and rubber plantations are & & & \\
\hline & sufficiently available & 0.083 & 6 & 0.498 \\
\hline 4 & There is livestock cultivation that has livestock production in the form of meat and eggs yields & 0.090 & 6 & 0.540 \\
\hline 5 & Abundant fruit & 0.089 & 8 & 0.712 \\
\hline 6 & Have tents that can be rented & 0.100 & 8 & 0.800 \\
\hline \multirow[t]{2}{*}{7} & Have agricultural equipment and machinery resources that can be used utilized & 0.089 & 6 & 0.534 \\
\hline & Weakness & & & \\
\hline 1 & Do not have the resources that can manage the rental of tents to the maximum & 0.085 & 3 & 0.255 \\
\hline 2 & Not able to build partnerships with other communities besides the sub-district & 0.090 & 3 & 0.270 \\
\hline \multirow[t]{2}{*}{3} & Do not have the ability to manage village land which is still unemployed & 0.087 & 2 & 0.174 \\
\hline & Total & 1.00 & & 5,905 \\
\hline \multirow[t]{2}{*}{ No } & External Strategic Factors (EFAS) & Score & Weighted & Score \\
\hline & Opportunity & & & \\
\hline 1 & BUMDes can act as distributors of agricultural, livestock, fishery, and plantation products & 0.089 & 8 & 0.712 \\
\hline 2 & BUMDes can manage tent rentals & 0.087 & 6 & 0.522 \\
\hline 3 & Develop processed fruit products & 0.100 & 8 & 0.800 \\
\hline 4 & Open village shops to help sell cultivation products & 0.089 & 8 & 0.712 \\
\hline \multirow[t]{2}{*}{5} & Manage untapped village land such as opening culinary stalls & 0.086 & 6 & 0.516 \\
\hline & Threats & & & \\
\hline 1 & $\begin{array}{l}\text { Competition with processed products from outside the region that are already favoured by the village } \\
\text { community }\end{array}$ & 0.095 & 3 & 0.285 \\
\hline 2 & Need sufficient capital in the utilization of village land which is still idle & 0.093 & 3 & 0.279 \\
\hline 3 & Marketing superior village products is not optimal & 0.098 & 3 & 0.196 \\
\hline 4 & Market share of services tent rental has not been worked out & 0.084 & 2 & 0.252 \\
\hline 5 & Business competition with middlemen & 0.090 & 3 & 0.270 \\
\hline \multirow[t]{2}{*}{6} & Agricultural products are very dependent seasonally & 0.089 & 3 & 0.267 \\
\hline & Total & 1.00 & & 4,811 \\
\hline
\end{tabular}

Based on Table 3, a matrix can be made based on two dimensions of organizational position, namely the position of the IFAS and EFAS analysis results in the strategy matrix, so that it is able to show the position of BUMDes. In the SWOT analysis assessment, the coordinate points are obtained on the axis of the SWOT analysis diagram (5,905: 4,811). The results of this analysis can be illustrated in Figure 1.

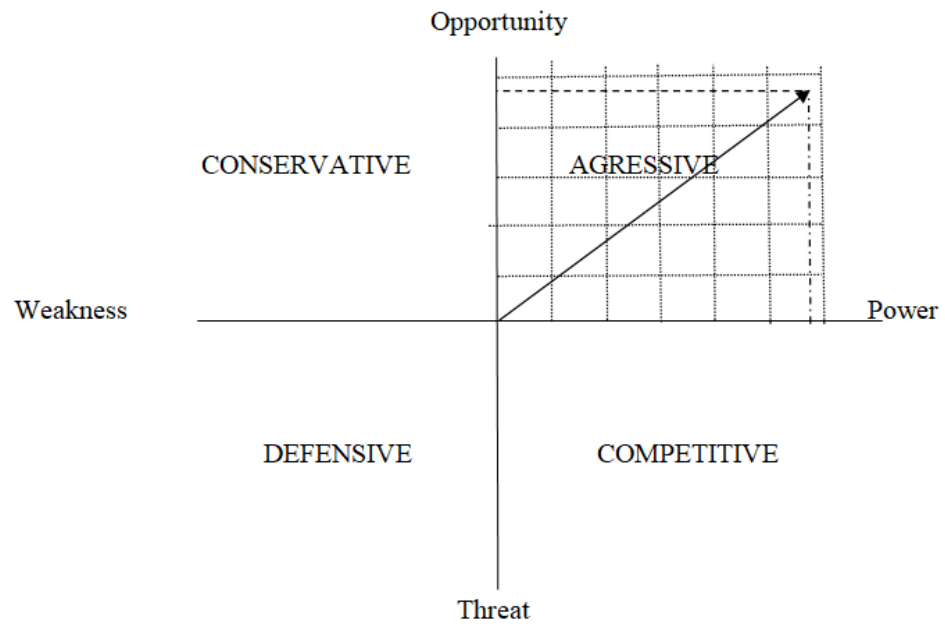

Figure 1 - Village BUMDes SWOT Analysis Matrix Kadundung

Based on the matrix in Figure 1 above, it can be seen that the Kadundung VillageOwned Enterprise (BUMDes) is in quadrant 2. The right strategy to use in the development of Village-Owned Enterprises (BUMDes) in Kadundung Village is to use an aggressive strategy. Aggressive strategy is a strategy in using the strengths of the company to overcome threats (Rangkuti, 2004). This strategy is used by taking advantage of long-term opportunities. The Kadundung BUMDes development policy using this strategy can be carried out by means of a diversification strategy (product / market). Differentiation is creating perceptions of certain values to consumers, for example perceptions of product performance excellence, product innovation, better service, and a superior brand image (Desritayanti 
2008). Several factors can be used as the basis for product differentiation, including core product differentiation, additional product differentiation, and service differentiation.

In differentiating this product, BUMDes Kadundung can differentiate products by taking advantage of its advantages as an abundant fruit producer to be processed into innovative and high-selling value products, such as processing fruit into fruit chips. BUMDes can take full advantage of unused machines and tools. In addition, Kadundung BUMDes can also differentiate services by acting as distributors of processed products that can become the superiority of Kadundung Village.

Apart from being based on a SWOT analysis, the direction of BUMDes development policy must also look at the efforts that have been and have not been carried out by the community. This is very important considering that the existence of BUMDes is not a competitor for the residents' businesses, but as a facilitator who can stimulate more development in people's businesses.

\section{CONCLUSION}

The existence of BUMDes in Kadundung Village is expected to be one of the drivers of the village economy. However, there are still many problems faced by Kadundung Village, such as aspects of institutional aspects, facilities, human resources, management, and finance. Village potential, superior products, adequate infrastructure, strategic area locations, are the advantages that can be used as opportunities to be utilized. The direction of the BUMDes development policy can be done by utilizing the abundant natural products which are the advantages of the village. The existence of this BUMDes is expected to be able to encourage the welfare of rural communities and to be stronger through cooperation with government programs.

\section{REFERENCES}

1. Ahmad, J. 2015. Metode Penelitian Administrasi Publik. Yogyakarta: Penerbit Gava Media.

2. Bambang, 2015. Pemetaan Arah Kebijakan Pengembangan Badan Usaha Milik Desa Di Kecamatan Kaligondang Kabupaten Purbalingga. STAIN Curup Bengkulu.

3. Chariri, Anis. 2009. Landasan Filsafat dan Metode Penelitian Kualitatif, Workshop Metodologi Penelitian Kuantitatif dan Kualitatif, Laboratorium Pengembangan Akuntansi (LPA). Fakultas Ekonomi Universitas Diponegoro Semarang, 31 Juli - 1 Agustus 2009.

4. Gunawan. 2004. Makalah untuk Pertemuan Dosen UKDW yang akan melaksanakan penelitian pada tahun 2005, URL: http://uny.ac.id, accesedat October 13, 15.25 WIB.

5. Madya, S. 2006. Teori dan Praktik Penelitian Tindakan (Action Research). Bandung: Alfabeta.

6. Nilawati, Evi. 2018. Analisis Manajemen Badan Usaha Milik Desa (BUMDesa) "Hanyukupi" Desa Ponjong Kecamatan Ponjong Kabupaten Gunungkidul. Jurnal Wacana Kinerja, Volume 21 , Nomor 1, Juni.

7. Setyobakti, M.H., 2017, Identification of Business Enterprises Bumdes Based on Social and Economic Aspect (Case Study At Bumdes Ijen Lestari Tamansari Village District of Banyuwangi), Jurnal IImiah Bidang Akuntansi dan Manajemen (JEMA) Vol. 14 No. 2 (2017).

8. Sofyani, H., Atmaja, R., and Rezki, S.B., 2019, Success Factors of Village-Owned Enterprises (BUMDes) Performance in Indonesia: An Exploratory Study, Journal of Accounting and Investment, vol. 20 no. 2.

9. Sulaksana, Jaka, dan Nuryanti, Irni, 2019 Strategi Pengembangan Badan Usaha Milik Desa (Bumdes) Kasus Di Bumdes Mitra Sejahtera Desa Cibunut Kecamatan Argapura Kabupaten Majalengka, Jurnal Ekonomi Pertanian dan Agribisnis (JEPA), Volume 3, Nomor 2.

10. Susyanti, Jeni, and Wahyu, Agung, M., 2019, The Analysis of Putukrejo Village Government Readiness in Forming BUMDes As a Development Efforts of Rural 
Communities based on Creative Economy, International Journal of Economics Business and Accounting Research (IJEBAR), Vol 3, Issue 3, October.

11. Syahrul, Efendi. 2019. Strategi Pengembangan Usaha Milik Desa Oleh Pemerintah Desa Rajadesa Kecamatan Raja desa Kabupaten Ciamis, Dinamika: Jurnal IImiah IImu Administrasi Negara, Volume 6,Nomor 4, Desember.

12. Widiastuti, H., Kresnawati, E., dan Utami, E.R., 2019, Pemetaan Potensi Desa dalam Rangka Mewujudkan Bumdes Di Kecamatan Moyudan, Jurnal BERDIKARI, Vol.7, No.1, Februari.

13. Yudiardi, Deni, dan Karlina, Nina, 2017, Identification Of Supporting And Inhibiting Factors Of Bumdes (Village-Owned Enterprises) Village Development Planning In Sukarame District Garut, Global Journal of Politics and Law Research, Vol.5, No.1, Februari. 